Sign Systems Studies 49(1/2), 2021, 108-131

\title{
Towards the semiotics of the future: From anticipation to premediation
}

\author{
Katre Pärn ${ }^{1}$
}

\begin{abstract}
The paper aims to make a contribution to semiotic research on the future by bringing together various approaches that deal with the relationship humans have with the future. More specifically, the paper concentrates on anticipation viewed as an activity that is based on modelling the (un)desired future as suggested by Nikolai Bernstein. The model-based approach to anticipation allows drawing connections between the psychophysiological and semiotically mediated forms of anticipation on the one hand, and between individual and collective forms of anticipation on the other hand. With these aims in mind, the paper offers a sketch of a semiotic approach to the future that is based on the framework of semiotic modelling systems, i.e. views the future in terms of models of it and the semiotic resources and processes involved in the model-building. As the semiotically mediated models of the future circulating in a culture can become collectively shared means of cognizing and anticipating some futures, it is possible to talk about a collective anticipation, analogous to Juri Lotman's cultural semiotic notion of collective memory. Accordingly, premediation, a future-oriented media practice outlined by Richard Grusin, is viewed as an example of collective anticipation.

In addition to tracing the mechanisms of anticipation from its individual organismic to semiotically mediated collective forms, the paper foregrounds also the two fundamental problems that run across the diverse theoretical perspectives brought together within the approach: the individual and collective agency in futuremaking and the affective dimension of anticipation.
\end{abstract}

Keywords: the future; semiotic modelling; anticipation; premediation; agency; affect

1 Department of Semiotics, University of Tartu, Jakobi 2, Tartu 51005, Estonia; e-mail: katre. parn@ut.ee. 
In a world of action-reaction, corresponding to a rather poor form of causality, semiotics is not necessary. Only in acknowledging the anticipatory condition of the living can grounding for semiotics be found. (Nadin 2012: 1)

\section{Introduction}

In the latter half of the 20th century, the future emerged as a central socio-cultural concern and as an explicit research object. This resulted in a shift from empiri$\mathrm{cal}$ and predictive approaches that model the future in terms of past and present occurrences towards possibilistic and constructivist approaches that are interested in a pluralistic and transformative dimension of future-making. This, in turn, has opened up a space for discussing the broader socio-cultural structures at work in shaping the future, as well as the individual, collective or institutional agency in future-making. Moreover, this has motivated the inclusion of social sciences and humanities into "the study of how different societies organize the future as a cultural horizon" (Appadurai 2013:5) in order to "become more aware of the roles that subjectivity, interpretation and cultural context play in shaping the way we understand and create the future" (Riedy 2008: 150). In this perspective, the future is not something that simply unfolds in a predictable or unpredictable manner from past and present circumstances, but a set of possibilities that are envisioned, represented, debated over, designed, chosen and fulfilled or disregarded by members of a community. The common view held by these approaches is that humans have unprecedented freedom in shaping or capability in steering their future.

The turn towards humanities in the studies of futures has been, at times explicitly, yet more often implicitly, a turn towards semiotics, i.e. towards the role played by meaning, interpretation, texts, discourses, images and ideas of the future, as well as by semiotically mediated interactions between individual and collective levels in future-making (e.g. Ogilvy 1996; Slaughter 1996; Inayatulla 1998; Hiltunen 2008; Ahlqvist, Rhisiart 2015; Kuusi, Lauhakangas, Ruttas-Küttim 2016; Goode, Godhe 20172; Godhe, Goode 2018³). However, while semiotics is accounted for, it is still not fully and productively present in the research into the future. Dario Martinelli $(2016: 80,89)$ has observed that while futures studies use extensively semiotic notions, there has been little explicit connection between the

2 Goode, Luke; Godhe, Michael 2017. Beyond capitalist realism - why we need critical future studies. Culture Unbound 9(1): 108-129. Available at http://www.cultureunbound.ep.liu.se/ contents.asp?doi=10.3384/cu.2000.1525.1791.

3 Godhe, Michael; Goode, Luke 2018. Critical future studies - a thematic introduction. Culture Unbound 10(2): 151-162. Available at http://www.cultureunbound.ep.liu.se/contents.asp?doi= 10.3384/cu.2000.1525.18102. 
disciplines. Hence, a discursive space as well as recognition of the necessity of semiotics has been established in research on the future. However, thus far, the space has been only tentatively and sporadically filled, even in semiotics, where the future, construction and representations of future are frequently discussed (e.g. Tobin 2004; Jameson 2005; Rosiek 2013; Tarasti 2016; Ceriani 2017; Seif 2019), yet there is no systematic "semiotics of the future".

This paper aims to make a contribution towards semiotic research on the future by bringing together various approaches that deal with the relationship humans have with the future in order to outline a perspective that would make it possible to study the connections between individual and collective capacities of future-making. More specifically, the aim is to connect the theoretical discussions on anticipation on the level of organisms with the problem of anticipative mediation on sociocultural level exemplified by the process of premediation.

Accordingly, the paper begins by outlining Nikolai Bernstein's psychophysiological approach to model-based anticipation that already entails the central semiotic concerns of future-making: the individual agency in model-building, the role of the models of the future in voluntary activity (i.e. in volitional future-making) and the affective dimension of anticipation. Moreover, Bernstein's approach is historically connected with Lev Vygotsky's theory of semiotic mediation and the theory of semiotic modelling of the Tartu-Moscow School of Semiotics. These will furnish the basis for a sketch of semiotic approach to the future in terms of the models of the future.

The approach foregrounds the role of semiotic resources (modelling systems and models) and semiotic mediation in anticipation and future-making. When the future is conceived in terms of the models of the future, it becomes necessarily plural, a field of alternative futures. It will be assumed that the extraordinary capacities of humans as future-makers depend on our modelling capacities, on the kinds of resources we use, the kinds of models we create and the ways we communicate (some of) the models across social groups. Semiotics allows us to understand the logic of cultural futurology on different levels (from individual to collective/socio-cultural), as well as the different steps in the process of futuremaking (from model-building to their fulfilment).

The relationship between micro- and macro-scale phenomena is, of course, far from direct, not only because of the change in scale - the shift from individual to collective phenomena (and interactions, mutual influences between the levels), but also due to the rather notable change in the complexity of semiotic mediation on the psychophysiological and sociocultural levels. Yet while the semiotic complexity has immense effects on the processes related to future-making, it is nevertheless useful to start by inquiring into the cognitive origins of anticipation 
in order to understand the basic mechanisms of anticipation and draw parallels between individual and collective forms of anticipation.

\section{Anticipation and models of the future}

In his programmatic article "The role of semiotics in the cybernetic study of man and collective" Vyacheslav Ivanov (1988[1965]) stated that the basic function of every semiotic system is the modelling of the world. These semiotic world models ${ }^{4}$ are usually shared by a community and introduced to each individual who becomes a member of the community, and they can also be regarded as programs for individual and collective behaviour (Ivanov 1988[1965]: 36-7). Ivanov envisioned semiotics as the study of the means used in constructing these world models and their diverse model-building functions, an approach that was developed further by the Tartu-Moscow School of Semiotics.

Ivanov's conception of semiotic world models governing individual and collective behaviour was itself inspired by the works of the Russian physiologist Nikolai Bernstein (1896-1966) $)^{5}$, according to whom the brain actively models the world, i.e. cognitive processes are modelling processes (Bernstein 2006b: 77). Models of reality are a prerequisite for any activity, for forming a program that guides the active behaviour of an organism ${ }^{6}$. I will use his theory of model-based anticipation to outline the process on individual psycho-physiological level. In view of individual agency in future-making, the relations between model-building and voluntary activity are of particular importance.

4 For the present purposes it is sufficient to define 'model', following Juri Lotman (2011[1967]: 259), as an analogue of an object of cognition that substitutes it in the process of cognition. As follows, the term 'modelling systems' refers to any semiotic resources and means used in model-building, from natural language to those used in arts, media, mathematics, statistics, etc. In alternative terminology, the modelling systems and models are the semiotic media entailed in the processes of semiotic mediation.

5 Bernstein did not, of course, develop his ideas in isolation. Similar ideas, particularly on model-based anticipation, were developed by his contemporaries Aleksej Uhtomskij (18751942) and Per Anohin (1898-1974) (for further information, see Nadin 2015a; Kurismaa 2015). However, I will hereby concentrate mainly on Bernstein as an explicit source for Ivanov. Note also that I will mainly refer to the ideas he formulated in the late 1950s and shortly before his death, although the papers were published and translated only more recently.

6 In addition to 'model', Bernstein also used the concepts 'reflection', 'image' or 'representation' of reality. While the concepts 'model', 'program', 'code', etc. may have been borrowed from the vocabulary of cybernetics, influential in biology, physiology as well as semiotics of that period (as is also evident already from the title of Ivanov's paper), here I am not concerned with the cybernetic background. Ultimately, 'model' became useful as a general term for the manifold of similar semiotic phenomena across domains. 
Bernstein's approach to the physiology of movement diverged from the then current understanding that behaviour is triggered by an external stimulus as an unconditioned or conditioned reflex or reaction to the stimulus. The reflexbased explanation of action had already been challenged by his contemporary Lev Vygotsky (1896-1934) in the 1920s; the latter's psychology of activity influenced Bernstein's physiology of activity (see Bongaardt, Meijer 2000: 64-65). ${ }^{7}$ In this context, activity [aktivnost'] does not only refer to action as such, but, more importantly, as opposite of passivity and reactivity, it implies initiative (Meijer, Bongaardt 1998: 3). Thus, voluntary actions differ from the movements that are determined by an external stimulus in that "not only the[ir] program but also the starting initiative is determined wholly from within the individual" (Bernstein 2006a: 39). Similarly, for Vygotsky "[the] self-generated stimulation, that is, the creation and use of artificial stimuli [signs] which become the immediate causes of behaviour" is the characteristic of higher mental function forming the basis for voluntary behaviour (Vygotsky 1979: 39). Accordingly, to understand living organisms' capacity for voluntary activity, one needs to understand the nature, formation and functioning of the self-generated stimulation that initiates and guides the activity.

Firstly, as Bernstein notes, the world is neither imprinted into nor represented in a brain passively, element by element, as an inventory of things existing in it. Instead, the brain actively and on-goingly divides, unites, systematizes, orders, etc. these elements (i.e. sensory information about them), discovers their significant relations or laws - in other words, reshapes the information into a model of the prototype world, and thereby also adds information from itself to the prototype. As a result, the information about the prototype contained in the model is simplified and more economical, and at the same time "enriched with meaning-related content" (Bernstein 2006a: 45-47). Or, as Lotman would later state in the context of secondary modelling systems, a model is not an automatic mirror of reality but an active means of its cognition, of knowing reality (Lotman 1981[1976]: 14-16). Thus, the capacity to model the world in the organism's own terms is a prerequisite for agency in future-making.

Secondly, voluntary action requires some degree of control and regulation, or, to be more precise, self-control and self-regulation, since external conditions can but rarely be controlled by individuals. However, as Bernstein (2006c: 94) observes, "control and controllability never and nowhere arise as goals in themselves, as things existing for their own sake [but] are required where a task of some kind is set, where one or another goal that is necessary to achieve is defined".

7 On the relationship between Bernstein and Vygotsky, see Feigenberg 2014: 44-59.

8 And here we could draw an obvious parallel with Jakob von Uexküll's notion of 'umwelt'. 
Hence, a prerequisite for control and regulation is some predetermined goal in a form of "a representation or outline of what this situation must become" (Bernstein 2006c: 94). In other words, a living being, in order to have voluntary control over its activity, must have goals, or more precisely, the capacity to plan ahead, have some grasp of a future that does not yet exist.

Accordingly, Bernstein differentiated between three ways in which the brain models the external world: by constructing (1) a model of the actual situation in the present moment; (2) a model of situations in the past stored in the memory; and (3) a model of a situation in the future that is yet to become reality (Bernstein 2006a: 40). The "model of required future" (Bernstein 2006b: 77), or the model of desired future, as he also called it, is the basis for anticipation, i.e. for the capacity to pretune oneself to "keep ahead of the movements" in the light of the desired outcomes of the situation (Bernstein 2006a: 52-53). In other words, the model of desired future functions as a self-generated stimulus necessary for voluntary activity. Thus, Bernstein not only conceived that subjects construct models of reality in order to behave adequately, but also suggested the idea of future-orientedness of these models: how the future - that does not exist yet, but is willed - is represented in individuals and impacts their present behaviour and choices. Moreover, to the extent that the adequacy of behaviour is determined by the self-generated stimulus, the model of desired future makes it possible to wield active influence on the world in ways that is predetermined neither by external conditions nor by past or present circumstances.

The world models are not mere generalizations or synthesis of past and present experiences, i.e. models of the world as it is or as has been, but they are also models of what has not existed yet. Vygotsky additionally noted that what makes it possible for humans to be future-oriented and alter their present by creating a future is their creative activity, imagination (Vygotsky 2004[1967]: 9). Before the future can be anticipated, it has to be imagined. While Bernstein concentrated mostly on the more basic cognitive functions, Vygotsky studied the so-called higher mental functions, whereby the control and voluntary regulation is additionally augmented by the use of signs and symbols - semiotic tools.

To foreground two central notions: semiotic systems are anticipatory systems and anticipation is a model-based activity. Anticipation explicates how the future enters into the causal sequence of activity, as pointed out by Mihai Nadin (2015b: 424-25): instead of the deterministic cause-and-effect relation of the reflex-based model, where the present behaviour is determined by the past, the model of the future allows, as a result of feed-forward processes, to seek "feedback" also from the projected future. As a result, the future emerges as a cause for current actions (Fig. 1). 


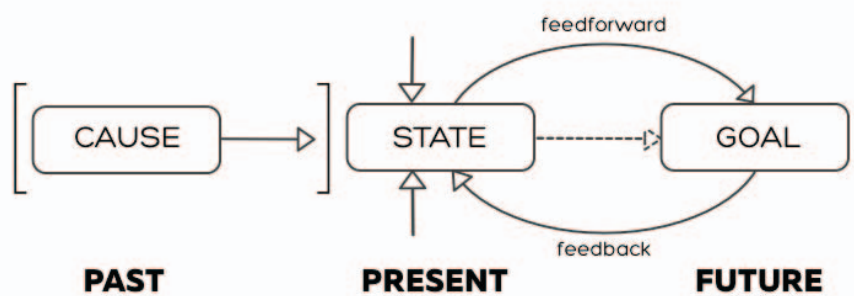

Figure 1. Future as cause for actions: feedback from the model of future in anticipative processes (adapted from Nadin 2015b: 424-5).

In other words, anticipation concerns the instances when the current state of a subject/system does not solely depend on the past or current states, but is also affected by the model of the possible future (Nadin 2016: 5). Thus, anticipation pertains to the modelling of the future as well as the present action taken with regard to the model of the future, in order to ensure that the desired future becomes actuality - or that undesired future does not. To the extent that the model of the future that initiates and guides the activity may be more or less independent, removed from the past or present circumstances, anticipation presumes an agency of a subject as a self-controlling, purposeful agent who is not simply passively reacting to external conditions, but is capable of creating his/her own stimulus for actions.

The issues of semiotic world models posed by Ivanov in 1965 differ from Bernstein's physiological account of activeness in scale and complexity, yet the core problematics remains the same. While Bernstein was mainly concerned with the level of neural and physiological processes, where the 'modelling language' or, in his terms, the code involved in the construction or formulation of the model of reality in the brain was yet unknown ${ }^{9}$, Ivanov and his fellow members of the Tartu-Moscow School of Semiotics were interested in semiotic processes on the socio-cultural level on which world models are constructed via various sign systems or semiotic resources used in human society. These sign systems function as modelling systems, means for model-building that, analogously, divide, unite, systematize, order - reshape and enrich - the information about the 'prototype' world captured in the models that guide human activity. Additionally, resorting to Vygotsky's cultural-psychological theory of activity, Ivanov (1988: 29-30) conceived of signs as means of control and regulation used for (self-)governing on an

9 Although Bernstein to some extent also discussed natural language, musical scores, and other additional means used by humans. 
individual as well as a collective level. In this view, the anticipatory capacities of semiotic systems (i.e. cultures, institutions, their members) are dependent upon the modelling systems and their affordances, as these have the potential to bring about extensive changes in the modelling capacities of semiotic systems.

From the cultural semiotic perspective, natural language was defined as a primary, grounding modelling system (see Lotman et al. 2013[1973]). In the context of general semiotics, Thomas Sebeok redefined the primary modelling systems in terms of zoosemiotic non-verbal modelling (see Sebeok 1991; Sebeok, Danesi 2000), thereby effectively integrating the embodied forms of psycho-physiological modelling discussed by Bernstein into the general framework of semiotic concerns. Within this framework, semiotic resources mediate, extend, amplify and reshape an organism's physiological and psychological capacities on which they are based, including that of anticipation - and become themselves extended, amplified and reshaped in further processes of (re)mediation via media technologies.

In this paper, I will refrain from discussing the relationship or co-dependency between the biological and cultural levels of semiotic modelling and concentrate on the processes of semiotic mediation and future modelling on the socio-cultural level, that is, on the role of anthroposemiotic resources (i.e. sign systems, cultural languages and media) in modelling the future. The semiotic layers that build upon the neurophysiological and embodied forms have their distinct semiotic affordances in modelling the past, the present and the future in terms of their modelling capacity, mode and modality ${ }^{10}$, particularly in terms of their spatiotemporal scope (distance from the here-and-now), collectivity (communality) and shareability.

Within the approach to culture developed by the Tartu-Moscow School, the future remained mostly a latent aspect of the modelling activity. Their approach concentrated more on mnemonic and structuring capacities of these systems or models, as well as their capacity to transcend individual knowledge and constitute a communal, i.e. cultural, memory, world-views and practices. However, the creative dimension of modelling activity, i.e. the capacity to create new information was constantly being foregrounded. ${ }^{11}$ The future became a more explicit, even central issue in Juri Lotman's Culture and Explosion (2004[1992]), where the view

10 Here I mean 'modality' in the sense used by Hodge and Kress (1988: 124), as referring "to the status, authority and reliability of a message, to its ontological status, or to its value as truth or fact".

11 Also, in early writings of the Tartu-Moscow School, the future, particularly future-orientation, is more explicitly mentioned as a typological dimension of cultures or texts; see, for example, Juri Lotman's approach to the modelling function of the beginning and the end (of a semiotic system, e.g. culture) in the context of artistic texts (e.g. Lotman 2006[1966]). 
of the future goes beyond causality, probability and possibility, discussing chance and randomness as a spring of unpredictability in historical processes, as well as in semiotic processes more generally, noting that "it is necessary to keep in mind the fact that the system has a memory of its past states and an anticipation of potential 'future states"' (Lotman 2004[1992]: 172).

I am using the Tartu-Moscow School's approach to culture as a system of secondary modelling systems as a general framework to bring together various semiotic dimensions of the emergence of the future as cultural fact and horizon, to use Appadurai's (2013) formulation. Thereafter, I propose a view on anticipation that is analogous to Lotman's cultural semiotic view on memory.

\section{Semiotic modelling and the future}

'The future', or to be more exact, knowledge of the future world ${ }^{12}$ as it exists in culture is a semiotic phenomenon par excellence, if one is to follow the strand of thought of the Pyrrhonian philosopher Sextus Empiricus. According to him, it is only through signs that one can know, "make present" and deal with things that are either temporarily or permanently unknown, unavailable, or perhaps even non-existent (Sextus Empiricus 2005: 118). Permanent unavailability to direct experiences as well as (f)actual non-existence are characteristics of the future. Without going into detail as concerns the peculiarity of the semiotic mode of existence of the future world and the conditions that make it possible, I broadly refer to aspects that are more relevant for the present discussion.

Firstly, the future as something which does not (yet) exist, can, thus, at present only be known via signs, or semiotic resources more generally. Whatever notions, ideas, knowledge we have of the future, these are past or present "representations", models of the future. And as models of a non-existent thing, models of the future are fictions that may have some degree of plausibility. The actual non-existence (as yet) of the future world affords constitutive, constructive and disruptive agency to living beings even in the face of things that do exist and can be predicted and presumed to exist in the future. ${ }^{13}$ Yet while the future does not (yet) exist, the models of the future can have quite tangible existence and turn (some) futures

12 Note that I am not discussing 'the future' as a general temporal category, but as a presumed future state of some world "captured" by some model. Moreover, out of convenience I will use the term 'model of the future' regardless of the scope of the model, i.e. whether it represents the "whole world" or some particular entity.

13 Although from the perspective of semiotic modelling, prediction as a semiotic act/model can itself become constitutive of the future present. 
into semiotic facts operational in the present with some capacity to pre-determine the future present, both on the individual and the collective levels. Through the 'crystallization' in tangible semiotic resources, the future becomes "a culturally organized dimension of human life" (Appadurai 2013: 294).

However, while the models of the future concern, properly speaking, those modelling activities that explicitly project or deal with the not-yet-existent future, the future is also a latent dimension of semiotic modelling more generally. One of the main functions of semiotic modelling systems and models is to extend the realm of the knowable and the predictable not only by acquiring and storing knowledge about the surrounding world but also by providing culture with models, programs, schedules, systems, goals, a "normality" that organizes and structures the sociocultural sphere. They allow further predictability by making it possible to forge and realize the present and the future in an organized manner, by acting in a way that is considered normal in a given culture. Once a culture internalizes a world model, it inhabits and fulfils the model world, at least to an extent. In that sense, all models and modelling systems may partake in pre-designing the future by providing the basis for the choices made and any world model shared by a community latently functions as a model implying some future, furnishing the sociocultural realm with a layer of predictability or foreseeability. In case of models of the future, dealing with the future becomes an explicit aim, often accompanied with additional kinds of modelling systems and practices designed for probing into the unknown future.

Secondly, as follows, the semiotic perspective necessarily problematizes the linear conception of time. The past, the present and the future are not separate islands that follow each other in time, but are in constant "cross-contamination". Similarly to Lotman's remarks, that due to cultural memory, "the past is never gone" (Lotman 2019[1985]: 135), due to the modelling of future and anticipation, the future is never absent. In their diverse manifestations, they co-exist in the present, as the past and the future are constantly semiotically present in the present stored, remembered, retold, remediated, predicted, foreseen, premediated, etc. via various semiotic resources. Moreover, the models of the future themselves have an ambivalent temporality; in Foucault's (1986: 26) terms, they are heterochronic - as representations, they are always products of the past or the present, yet are perceived as having a futurity. Their futurity is itself a semiotic notion that allows to perceive them differently from other fictions or products of imagination.

Thirdly, while the future as a temporal dimension can be perceived as homogeneous, from a semiotic perspective, 'the future' is always heterogeneous and plural, as it exists in the form of a variety of models entailing a variety of futures with various degrees of (un)certainty, (im)possibility and (im)plausibility. Thus, 
in the semiotic view, it would be more proper to speak of 'futures', of a plurality of models of the future circulating in the culture. What, then, becomes a relevant question for semiotic study is the role and impact of particular modelling systems, as well as their hierarchy in a particular culture, on how these models are evaluated, valued and used in the culture.

To understand how the non-existent, unavailable sphere of the future is made present, knowable, available in a culture as well as the consequences of such objectivation of the future one needs to study the semiotic fabric of the culture: the modes, resources and practices through which the culture engages and copes with absence and change. The future-orientation of a community does not depend solely on the availability of models of the future, but presumes also the availability of the means for and practices of modelling the future. It is about the semiotic resources used in constructing the models of the future (e.g. natural language, cinema, tarot cards, statistics), their impact on the contents and modality of the models as well as on the future present. The impact can be evaluated either in terms of the modelling capacities of the resources, their semiotic affordances, distribution and availability, etc., or in terms of the semiotic practices - inferring, predicting, foreseeing, forecasting, making prognosis, aspiring, imagining, planning, premediating $v i s-\grave{a}-v i s$ the resources affording or facilitating these practices. It can also be evaluated with regard to the repertoire of "genres" or formats of cultural futurology such as prophecy, destiny, myth, divination, premonition, prognosis, vision, goal, trend, utopia, sci-fi, scientific prediction, etc. available in the culture.

On the other hand, there is the question of the availability, legitimacy and distribution of the models themselves, the sociocultural position of their producers or distributors, as well as the social and communicative affordances of the resources and practices involved in the process that make it possible for the models to be shared among a smaller or larger community, and for some of the models to dominate over others. Beyond that, there is also the question of the usability, use and usefulness of the models of the future available in culture and modulating the degree of control and freedom of the activity of its members.

Yet as Appadurai (2013: 287, 293; emphasis added, K. P.) reminds us, the future as it exists in culture is not simply a matter of techniques or resources but " $\mathrm{t}] \mathrm{he}$ many forms that the future takes are also shaped by [..] affects and sensations" such as awe, hope, excitement, disorientation, fear, etc. that give them "their specific gravity, their traction and their texture". While he aims to foreground hope and aspiration as keys for a better future, he also notes that more attention has been paid to practices related to fear and avoidance. 


\section{Anticipation and the unforeseeable}

In terms of knowability and inferrability of what the future holds, Jacques Derrida has made a distinction between two kinds of futures: (1) the future that will be [futur], "a future that is predictable, programmed, scheduled, foreseeable" and thus knowable ${ }^{14}$; it follows from the present, allowing planning for it; and (2) the future to come [avenir], which Derrida calls "the real future", the open future of things to come, the arrival of which is unexpected and unpredictable, and cannot be anticipated or foreseen (Zehfuss 2007: 104). Bernard Stiegler (1998: 6) calls it "the horizon of authentic possibilities". In the former case we are dealing with the future that can be known, assumed, predicted from that which is or has been. In the latter case, one does not know, or even cannot know what is to come before it arrives. For Derrida, "the real future" is open and offers unimagined possibilities, but as something that is ultimately unknown and unforeseeable, it "can only be anticipated in the form of an absolute danger" (Derrida 1997[1967]: 5; Zehfuss 2007: 104).

However, the fact that the future-to-come is ultimately unknowable does not mean that it is excluded from the sphere of culture, deemed something that cannot be "represented" or modelled. Quite the contrary - the looming unknown is dealt with by an abundance of modelling activities aimed at filling the void and/or exploiting the space of possibilities it provides. It becomes a locus of imagination and creativity. Here we can resort to Vygotsky's view that imagination affords to humans the capacity to deal with future. Following the Vygotskian line of thought, Pelaprat and Cole (2011:399) view thinking and imagination as mechanisms for forming a more or less stable image of the world in the face of inevitable scarcity of (sensory) information, or as processes of "gap-filling". As culturally and semiotically mediated psychological functions, thinking and imagination have a futureoriented character, being aimed at "reducing the uncertainties about the future so that one can think or act in the present. To imagine is to imagine a future in which thought and action can be meaningful" (Pelaprat, Cole 2011: 404-5).

The cultural or semiotic mediation affords new forms of imagination, a more radical shift from experience- and perception-based modelling to language-based modelling, or in Paul Ricoeur's terms, from reproductive to productive imagination (Ricoeur 1979). However, not only does productive imagination allow one to imagine new things, but it also makes it possible to "crystallize imagination" ${ }^{15}$, to

14 Quotes by Derrida are from the documentary Derrida (Kirby Dick, Amy Ziering Kofman 2003) - quoted via Zehfuss 2007: 104.

15 Vygotsky borrows the phrase 'crystallized imagination' from Théodule Ribot's Essai sur l'imagination créatrice (1900). 
embody it in external, material form, allowing it to become an object that exists in the real world and thereby has the possibility to affect other things and people to become reality (Vygotsky 2004[1967]: 20). Pelaprat and Cole view the social dimension of imagination in regard of various (digital, etc.) media that extend imagination temporally and spatially, remediate and socially expand the image of the world - a process they call "social proprioception" (Pelaprat, Cole 2011: 410ff). Thus, to draw a tentative conclusion, semiotically mediated imagination allows us to fill the empty space of the future-to-come with an array of models of possible or imaginable futures and crystallize them as socially available, shareable elements of cultural reality - contingent or other.

Appadurai's (2013) notion of humans as future-makers who produce the future as a cultural fact and a cultural horizon can, consequently, be conceived of on two interrelated levels: on the one hand, humans as model-builders who have extensive resources and capacities for modelling the future, and who produce an abundance of models of the future; on the other hand, humans as anticipative creatures who have an extensive capacity to influence their future present through the models, to predesign or, to an extent, pre-determine the future states of the world by fulfilling, realizing some model of the future.

While the models of the future that guide individual and collective behaviour imply some control over their users, the plurality of models, in turn, implies a possibility of choosing between them, thereby affording additional degrees of freedom in the face of the future that is unfolding. From that perspective, it becomes necessary to understand the creation, circulation and choice of the models of the future in culture. While future-oriented practices are ubiquitous in culture and society, I will take an example from the circulation of models of the future in the media, as mainstream media have a central role in the construction of public concerns and assigning collective dimension to affects, imaginaries and choices for actions, and as such form an integral part of the semiotic framework of anticipation.

\section{Premediation and collective anticipation}

The notion of an 'anticipatory system' does not, in itself, necessarily refer to an individual agent, be it a living or an artificial organism, but can be extended to larger collectivities or institutional formations. In this sense, any semiotic system on any level of integration can be viewed as an anticipatory system, including culture, when it actively engages with modelling the future in order to shape its present activities via the model(s) of the future. As mentioned above, in semiotics of culture, the mnemonic function has been considered as central for culture seen 
as "the sum of all non-hereditary information and the means of its organisation and preservation" (Lotman 2010[1970]: 29). As Lotman (2019[1985]: 133) notes:

From the point of view of semiotics, culture represents collective intelligence and collective memory, that is, a supra-individual mechanism for preserving and transmitting messages (texts) and for creating new ones. In this sense, the field of culture can be defined as a space of shared memory, within which certain common texts are preserved and actualized.

Cultural memory, or the shared memory of a community, is formed of texts that store past experiences relevant for the community, and despite the unity that is established "by the presence of certain textual constants" and "by a single code", it is also internally diverse, as different cultural substructures are differently organized and have different memory capacities (Lotman 2019[1985]: 133-4).

Analogously, models of the future are embodied and mediated in culture via a variety of semiotic resources making them publicly available and constitutive of collective imagination and anticipation of a communal future or, rather, of a dynamic and diverse set of possible futures with various scopes and modalities. These models of the future circulating in culture can influence both individual and institutional choices of action made in anticipation of some desired or undesired future. Collective anticipation resorts to the anticipative processes on the level of the individual but by furnishing the imagination of individuals with shared models of the possible future it begins to guide their collective action. Analysis of the possible parallels or differences between the semiotic aspects of collective/ cultural modes of memory and those of anticipation, however, remains outside the scope of the present paper. What is relevant here is that from the perspective of individual as well as sociocultural functioning, both anticipation and memory are semiotically mediated, and in case of collective anticipation, as with collective memory, we are dealing with complex intertwining of transindividual sociocultural and individual psychological processes.

At this point I will exemplify the issue with a modelling practice that can be taken as a means for furnishing the temporal horizon for collective, sociocultural anticipation, that is, a process of anticipating the near future, but on a collective scale. I will take the phenomenon of premediation as outlined by Richard Grusin as an example of this kind of modelling of the future that makes collective anticipation possible. Premediation is far from being the only form of collective anticipation, yet as it concerns mainstream media, it also illustrates the role of media culture in these processes.

Grusin is among the media scholars who have pointed out the growing obsession with the future in contemporary culture and particularly in news media. $\mathrm{He}$ 
observes that while in the 20th century the cultural dominant of the media was recording and reusing the past, by the turn of the century telecommunications and digital technologies had brought along a devotion to real-time monitoring and reporting of the world, accompanied by a desire to regain a sense of immediacy, direct and instant access to reality through what Bolter and Grusin (2000) called "hypermediation" of contents on multiple screens and devices in any mode available. This, in turn, was followed by a desire to "stay ahead of events" - not simply to break the news as soon as an event happens, but to report it before it has actually arrived, thereby turning possible futures into present concerns. This "anticipatory temporality" (Grusin 2010: 129) in the media affords "controlling the future itself, to the extent at least that the future arises out of anticipations or expectations" (Hansen 2006: 304).

Grusin $(2004,2010)$ introduced the concept of premediation to describe the specific form of modelling of the future that became dominant in mainstream media. The aim of the new cultural logic of mediation is to premediate the future before it happens, and particularly news media have assumed "a prophetic or predictive role of reporting on what might happen” (Grusin 2004: 23). As such, premediation is an example of a large-scale socio-cultural modelling activity that does not necessarily involve modelling the future in the long term, as more or less abstracted from everyday practices, but is rather about setting up or negotiating some shorterterm agenda requiring "feedback" from the future. It also serves as an example of the influence that news media, as a specific semiotic system with its peculiar logic and repertoire of semiotic resources and practices, have on the models of the future circulating in a culture as well as their impact on decision-making.

In the context of the US, Grusin views $9 / 11$ as the turning point from remediation to premediation as a dominant cultural and media practice. This makes premediation a cultural response to an unpredictable and traumatic event that is aimed at ensuring that the society would not have again the immediate, unexpected experience of a catastrophe by attempting to premediate everything before it actually happens (Grusin 2004: 20-21). Proceeding from the events of 9/11 assigns premediation also a specific affective disposition augmented, in turn, by the affective logic of mainstream media. Grusin views premediation as an early warning system, a means of modulating fear that allows one to prepare emotionally for any events that might come. As one cannot predict the future occurrences of catastrophic events, one can at least ensure that their arrival would not be experienced as a traumatic shock by "maintaining a low level of fear and anxiety" (Grusin 2010: 2) via constantly premediating the possibilities of a future catastrophic event. The emotional pretuning itself depends on the affective propensity or logic of media culture (Grusin 2010: 79) and of the notion of "newsworthiness" 
that has a specific impact on the choice of the models of the future circulating in mainstream media or, thereby, on action taken in response to the news. Moreover, in a different context Appadurai (2013: 299) characterizes the affective pretuning towards fear and trauma as an "affective crisis" in future-making that impairs the capacity to aspire or hope for a different future. The anticipative temporality of premediation turns into prevention and avoidance of a catastrophe rather than aspirational and constructive future-making.

As an example of the logic of premediation, Grusin analysed the participation of the media in premediating the economic catastrophe in 2008, resulting in the approval of a $\$ 700$ billion bailout to financial institutions (Grusin 2010) as well as the media coverage leading to the war in Iraq, which was premediated in a way that made it seem as an inevitable future (Grusin 2004, 2010). In both instances, he observes, the action was taken not in a response to an existing catastrophe, but in response to a premediation of a catastrophe, as a pre-emptive activity in anticipation of a catastrophe that would or might have come, had certain actions not been taken (Grusin 2010: 148).

More recently, premediation was at work in the global media coverage of the coronavirus pandemic, where reporting of the present state has been intertwined with premediations of possible dire social, economic and cultural futures. The individual or institutional responses were thereby inevitably influenced by the premediation of possible future states that might or might not arrive. Being prepared and able to anticipate future events is crucial in preventing or dealing with crises. However, the question arises as to the effects that the particular practices and forms of constructing the models of possible futures in mainstream media have on individual and collective responses, particularly beyond the medical or health-related domains. On the one hand, this concerns the blurred boundary between predictions, prognosis and premediations, the impact of semiotic resources used in model-building on the perceived "truth-value" of the projected futures. On the other hand, this concerns the influence of media logic (e.g. Altheide, Snow 1979) on the models of the future that are disseminated in news media and influence the decision-making.

What makes the future-oriented practices of mainstream media of particular interest is precisely their capacity to influence behaviour and choices, both on the individual and institutional levels, to set a collective agenda through modulation of collective affect and prefiguration of collective imagination. Processes like premediation allow us to understand how prefiguration of imagination can turn into prefiguration of events.

Grusin's discussion on premediation bears some similarities with Lotman's discussion on cultural explosion and its aftermaths. The moment of explosion can be seen as a sudden turn in social temporality from future-as-predicted to 
unpredictable future, to what Derrida called 'lavenir'. In the cases Grusin gives as an example, the US has been thrown into a limbo by unforeseen events (the 9/11 terrorist attacks in 2001 and the sub-prime mortgage crisis in 2007). In Lotmanian terms, these events functioned as moments of explosion, as a result of which "the whole chain of previously possible future events" had been broken, the future had become uncertain, turned into "the space of possibilities", where, instead of causality or probability, chance served as a basis for choice (Lotman 2004[1992]: 13-14). In the moment of explosion, anything becomes possible as "the uncertainty of the future allows significance to be assigned to everything" (Lotman 2004[1992]: 13). The choice of the element to become the dominant that will determine the future movement is unpredictable, it is chosen by chance, although at the very next moment it will have created its own predictable chain of events (Lotman 2004[1992]: 14).

In the process of premediation, this open space of possibilities is filled by the proliferation of scenarios that map out "as many of the possible worlds, or possible paths, as the future could be imagined to take" (Grusin 2004: 28). However, as noted, the possibilities are also framed by the (affective) logic of media. The obsessive premediation can be seen as a tactics for dealing with and managing the unknowable and unpredictable future (see Grusin 2010: 13). The unknowable future with its unimaginable possibilities is conquered precisely through imagining as many possibilities as conceivable. Moreover, the openness of the future-tocome makes it a favourable subject for news media that is in constant demand for new content - the future-to-come does not pose rigid limitations to the content nor necessitate or even allow the confirmation of accuracy or facticity of the future-oriented information, as anything could be possible or significant. While the premediations of future events might be loosely anchored in current data or past events, as "representations" of an unknowable future they nevertheless mainly have to do with imagination. This assigns them a peculiar position within news media that is habitually conceived as non-fictional reporting, for in the context of news media, these premediations become framed and perceived as non-fiction. This assigns to the projected futures a plausibility different from what can be assigned to imaginary scenarios in cinema, ${ }^{16}$ literature etc. As such, premediation as a media genre has a peculiar modality and an ambivalent position between fiction and non-fiction.

Since future-to-come cannot be properly predicted or known before it arrives, by envisioning "all" possible, or at least conceivable or imaginable, paths that can

16 For a discussion on the difference between news coverage of $9 / 11$ and cinematic, fictional depictions of similar events, see King 2005; Grusin 2010: 13-4. 
or might be taken, premediation provides a virtual roadmap to the future and "trie[s] to ensure that whatever form the future takes it will emerge only within the possible futures enabled by premediated networks of technical, social, and cultural actors" (Grusin 2010: 50). Through this, premediation becomes a means for prefiguring collective imagination. For Grusin, the central tactics of premediation is to turn the open, unpredictable future-to-come into a future as "predicted", or, more precisely, as premediated. As he notes, premediation is not about predicting the future correctly and getting it right, but about making it appear, once it arrives, as foreseen, or even as an inevitable outcome (Grusin 2010: 45-6).

Both Lotman and Grusin emphasize that while in hindsight the outcome might seem as inevitable and predetermined, at the moment of explosion the future becomes unpredictable, anything becomes possible. For Lotman (2004[1992]: 15-17), this seeming inevitability of the outcome is part of the cultural logic of explosion, a peculiar characteristic of hindsight, of the view from the present to the past that emerges after the explosion has been exhausted. Cultural descriptions of these events re-establish continuity by removing chance, i.e. the unpredictable choices, from the process and transform it into a historically predetermined cause-and-effect chain, seeds of which now seem to have been present all along. Retrospectively the events are experienced as goal-directed action (Lotman 2004[1992]: 158). As Lotman (2004[1992]: 15) puts it:

In this way [through reflection] a radically transformative event occurs: that which occurred, as we have seen, by chance, now appears to be the only possibility. The element of unpredictability is substituted in the mind of the observer by an element of regularity. From this point of view, the choice [by chance] was fictitious; in "objective" terms it was predetermined by the entire cause-effect motion of the preceding events.

Grusin, on the other hand, is more concerned with the role and logic of futureoriented mediation during the unfolding explosion and its aftermaths: how premediation of the future possibilities creates an anticipative temporality where, in view of the mechanism of anticipation outlined at the beginning of the paper, the models or visions of future influence the choices made in the present. While the future path is not historically predetermined, the process of premediation becomes so-to-speak the carrier of the seeds of future and makes some choices or outcomes more plausible and salient.

Premediations create their own path-dependence - set of "known futures" to turn to, to anticipate. In addition to the effects of media logic in terms of affective pretuning, the perceived plausibility of the scenarios can be enhanced by the 
formal features or modality markers of the premediations. As Kress and Leeuwen (2006) have noted, the credibility, certainty of an item of information depends on textual cues, modality markers that are established by a community in order to determine the factuality, the truth-value of messages. Grusin (2010: 46-7), in turn, points out how the distinction between premediation of possible future events and reporting of present events in real world is blurred through the use of the same formal modes of representation:

[...] the premediation of war in Iraq on cable news networks, for example, involved remediating any number of possible futures by means of the very formal features with which the war itself would be remediated (maps, retired generals, split-screen debates, video clips, and so forth) [...]. The emerging conventions of premediation [...] required that the future prosecution of the War in Iraq, for example, be premediated in ways that are almost indistinguishable from the way it would be remediated when it happens, prompting an affective orientation towards the war that prepared the media public to accept it as a fait accompli when it actually happened.

Premediation, he notes, does not imitate the experience of the "real" events, but the codes and practices of mediation of the "real". According to Grusin (2010: 43), it was the formal indistinguishability between premediation of possible events in future and mediation of actual events that contributed, according to Grusin, to the sense of inevitability of the Iraq War, as it already seemed to be a televisually mediated news event before it actually happened (Grusin 2010: 43). The status of actuality or plausibility of the premediated future is further enhanced by remediation and hypermediation of the scenarios across modes and channels. As King (2005: 49-50) noted in the context of 9/11 coverage: "[...] the fact that the same material was being presented on all networks at the same time underlined its status not just as 'reality', but as reality considered to be of a high order of impact and importance".

By prefiguring (collective) imagination, furnishing the "collective mind" with a set of future possibilities associated with a certain affective dimension, premediation provides a peculiar infrastructure for the future, having the capacity to turn into a self-fulfilling prophecy by limiting the realm of possibilities and by turning some alternatives more plausible and inevitable than others. Moreover, Grusin (2010: $57-8$ ) views the desire to premediate the future as the desire to colonize the future by media practices and technologies - to be present in the future. The desire goes beyond media technologies, as was evident during the COVID-19 crisis when agents from diverse fields participated in the (pre)medation of the crisis and its aftermaths, attempting to ensure their relevance (or relevance of their products and services) in (bringing about) the post-COVID-19 world. 
The logic of premediation outlined by Grusin is but one of many future-oriented practices in culture and is itself moulded by broader media logic, particularly in terms of mobilizing affect, imagination, meaning and behaviour. Yet it allows to outline some of the ways in which semiotic modelling and mediation of the future has the capacity to impact or determine current actions and choices on an individual as well as on a collective scale.

\section{Conclusions}

The semiotic study of the future firstly concerns the capacity to model a nonexistent object (future states) and, secondly, the capacity of the non-existent object thereby to impact or determine someone's current action and choices. In between lies the question of modes, modalities, affective logic and semiotic affordances of the models as well as related semiotic processes that afford, enhance or deny these capacities. From the perspective of anticipatory future-making in which the future is an open field of possibilities and humans are active agents capable of voluntary action who self-generate or construct the models that guide their choices and actions, the question of relation between "the horizon of authentic possibility" of undetermined future and that of the "horizon of anticipation" that aims to determine possibility (Stiegler 1998: 6) becomes a question of control over one's own future. Against the background of premediation and similar practices of dealing with the future-to-come lies the problematics of "openness" and "closedness" of the future, or of opening up or closing down the possibilities for alternative futures: how lavenir as the open future of unimaginable possibilities is turned into future-as-imagined and future-as-predicted (or premediated), or, vice versa, how a seemingly predictable future can be opened up, turned into future-to-come with undetermined possibilities.

The capacity of future-making depends on the repertoire of semiotic resources and practices available to an individual or a social group, as well as the logic of semiotic systems within which the models of the future are constructed and circulated. In terms of understanding the individual and collective agency in futuremaking as well as building the capacity of future-making, further understanding of the dynamics between the individual and collective spheres is necessary.

However, what becomes noticeable when we trace the problematics of anticipation from the psycho-physiological level to semiotically more complex individual and collective processes is that while the semiotic resources and means of mediation change, the models of future(s) and the processes of modelling grow in scope and complexity. The affective dimension of anticipation remains 
a constant undercurrent already marked by Bernstein's notion of the 'model of desired future' or the issue of fear. As anticipation functions through mobilization of affect, imagination, meaning and behaviour, the affective pretuning of premediation towards fear and catastrophe avoidance sets latent limits to the realm of envisioned future possibilities, foregrounding the prevention of undesired futures instead of modelling the desired future.

\section{References}

Ahlqvist, Toni; Rhisiart, Martin 2015. Emerging pathways for critical futures research: Changing contexts and impacts of social theory. Futures 71: 91-104.

Altheide, David L.; Snow, Robert P. 1979. Media Logic. (Sage Library of Social Research 89.) Beverly Hills, London: Sage Publications.

Appadurai, Arjun 2013. The future as cultural fact. In: The Future as Cultural Fact: Essays on the Global Condition. London, New York: Verso, 285-300.

Bernstein, Nikolai 2006a. Paths and tasks of the physiology of activeness. Journal of Russian and East European Psychology 44(2): 35-59.

Bernstein, Nikolai 2006b. New lines of development in the physiology and biology of activeness. Journal of Russian and East European Psychology 44(2): 68-92.

Bernstein, Nikolai 2006c. From reflex to model of the future. Journal of Russian and East European Psychology, 44(2): 93-98.

Bongaardt, Rob; Meijer, Onno G. 2000. Bernstein's theory of movement behavior: Historical development and contemporary relevance. Journal of Motor Behavior 32(1): 57-71.

Bolter, Jay; Grusin, Richard 2000. Remediation. Understanding New Media. Cambridge, London: The MIT Press.

Ceriani, Giulia 2017. The study of the future, social forecasting, mutations: Semiotic challenges and contributions. Semiotica 219: 471-484.

Derrida, Jaques 1997[1967]. Of Grammatology. Baltimore, London: The John Hopkins University Press.

Feigenberg, Josef M. (ed.) 2014. Nikolai Bernstein: From Reflex to the Model of the Future. (Studien zur Geschichte des Sports 17.) Zürich, Münster: LIT Verlag.

Foucault, Michel 1986[1984/67]. Of other spaces. Diacritics 16(1): 22-27.

Grusin, Richard 2004. Premediation. Criticism 46(1): 17-39.

Grusin, Richard 2010. Premediation: Affect and Materiality after 9/11. New York: Palgrave Macmillan.

Hansen, Mark B. N. 2006. Media theory. Theory Culture Society 23: 297-306.

Hiltunen, Elina 2008. The future sign and its three dimensions. Futures 40: 247-260.

Hodge, Robert; Kress, Gunther 1988. Social Semiotics. Ithaca: Cornell University Press.

Inayatullah, Sohail 1998. Causal layered analysis: Poststructuralism as method. Futures 30(8): 815-829.

Ivanov, Vyacheslav 1988[1965]. The role of semiotics in the cybernetic study of man and collective. In: Lucid, Daniel (ed.), Soviet Semiotics: An Anthology. Baltimore: Johns Hopkins University Press, 27-38. 
Jameson, Frederic 2005. Archaeologies of the Future: The Desire Called Utopia and Other Science Fictions. London, New York: Verso.

Kress, Günther; Leeuwen, Theo van 2006. Reading Images: The Grammar of Visual Design. London, New York: Routledge.

King, Geoff 2005. "Just like a Movie"?: 9/11 and Hollywood spectacle. In: King, Geoff (ed.), The Spectacle of the Real: From Hollywood to 'Reality' TV and Beyond. Bristol, Portland: Intellect, 47-57.

Kurismaa, Andres 2015. On the origins of anticipation as an evolutionary framework: Functional systems perspective. International Journal of General Systems 44(6): 705721.

Kuusi, Osmo; Lauhakangas, Outi; Ruttas-Küttim, Ruuta 2016. From metaphoric litany text to scenarios - how to use metaphors in futures studies. Futures 84: 124-132.

Lotman, Yuri 1981[1976]. Semiotics of Cinema. (Suino, Mark E., trans.; Michigan Slavic Contributions 5.) Ann Arbor: The University of Michigan Press.

Lotman, Juri 2004[1992]. Culture and Explosion. (Clark, Wilma, trans.; Grishakova, Marina, ed.) Berlin, New York: Mouton de Gruyter.

Lotman, Juri 2006[1966]. Mõistete 'lõpp' ja 'algus' modelleerivast tähendusest kunstitekstides. [On the modelling role of the concepts of 'the beginning' and 'the end' in artistic texts]. Acta Semiotica Estica III, 225-232.

Lotman, Juri 2010[1970]. Kultuur ja informatsioon. [Culture and information]. Kultuuritüpoloogiatest. [Typologies of Culture]. Tartu: University of Tartu Press, 26-30.

Lotman, Juri 2011[1967] The place of art among other modelling systems. Sign Systems Studies 39(2/4): 249-270.

Lotman, Juri 2019[1985]. Memory in a culturological perspective. In: Tamm, Marek (ed.), Juri Lotman - Culture, Memory and History. Essays in Cultural Semiotics. Cham: Palgrave Macmillian, 133-137.

Lotman, Juri M.; Ivanov, Vjacheslav V.; Pjatigorskij, Aleksandr M.; Toporov, Vladimir N.; Uspenskij, Boris A. 2013[1973]. Theses on the semiotic study of cultures (as applied to slavic texts). In: Salupere, Silvi; Torop, Peeter; Kull, Kalevi (eds.), Beginnings of the Semiotics of Culture. (Tartu Semiotics Library 13.) Tartu: University of Tartu Press, 53-77.

Martinelli, Dario 2016. Arts and Humanities in Progress: A Manifesto of Numanities. New York: Springer.

Meijer, Onno G.; Bongaardt, Rob 1998. Bernstein's last paper: The immediate tasks of neurophysiology in the light of the modern theory of biological activity. Motor Control 2: 2-9.

Nadin, Mihai 2012. Reasessing the foundations of semiotics: Preliminaries. International Journal of Signs and Semiotic Systems 2(1): 1-31.

Nadin, Mihai (ed.) 2015a. Anticipation: Learning from the Past. The Russian/Soviet Contributions to the Science of Anticipation. (Cognitive Systems Monographs 5.) New York, London: Springer.

Nadin, Mihai 2015b. Anticipation - the underlying science of sport. Report on research in progress. International Journal of General Systems 44(4): 422-441.

Nadin, Mihai 2016. The (almost) impossible task of interdisciplinarity. In: Nadin, Mihai (ed) Anticipation Across Disciplines. (Cognitive Systems Monographs 29.) Cham, etc.: Springer, 1-8. 
Ogivly, James 1996. Futures studies and the human sciences: The case for normative scenarios. In: Slaughter, Richard A. (ed.), New Thinking for a New Millennium. London, New York: Routledge, 26-83.

Pelaprat, Etienne; Cole, Michael 2011. "Minding the gap": Imagination, creativity and human cognition. Integrative Psychological and Behavioral Sciences 45: 397-418.

Ricoeur, Paul 1979. The function of fiction in shaping reality. Man and World 12: 123-141. Riedy, Chris 2008. An integral extension of causal layered analysis. Futures 40(2): 150-159.

Rosiek, Jerry Lee 2013. Pragmatism and post-qualitative futures. International Journal of Qualitative Studies in Education, 26(6): 692-705.

Sebeok, Thomas 1991. In what sense is language a 'primary modeling system'? In: Anderson, Myrdene; Merrell, Floyd (eds.), On Semiotic Modeling. Berlin, New York: Mouton de Gruyter, 327-339.

Sebeok, Thomas; Danesi, Marcel 2000. Forms of Meaning: Modelling Systems Theory and Semiotic Analysis. (Approaches to Applied Semiotics 1.) Berlin, New York: Mouton de Gruyter.

Seif, Farouk Y. 2019. Beyond forecasting and prediction: The role of phantasmagorial memory in imagining the future. Вісник КНЛУ. Серія Філологія 22(1): 88-99.

Sextus Empiricus 2006. Against the Logicians. (Cambridge Texts in the History of Philosophy.) Cambridge: Cambridge University Press.

Slaughter, Richard A. 1996. Futures Studies: From individual to social capacity. Futures 28(8): 751-762.

Stiegler, Bernard 1998[1994]. Technics and Time, 1. The Fault of Epimetheus. Stanford: Stanford University Press.

Tarasti, Eero 2016. Metaphors, semiotics, and futures studies. Futures 84: 120-123.

Tobin, Yishai 2004. Divination and futurology. In: Posner, Roland; Robering, Klaus; Sebeok, Thomas A. (eds.), Semiotics: A Handbook on the Sign-Theoretic Foundations of Nature and Culture. Vol. 4. Berlin, New York: Walter De Gryter, 3357-3371.

Vygotsky, Lev 1979. Mind in Society. The Development of Higher Psychological Processes. Cambridge, London: Harvard University Press.

Vygotsky, Lev 2004[1967]. Imagination and creativity in childhood. Journal of Russian and East European Psychology 42(1): 7-97.

Zehfuss, Maja 2007. Derrida's memory, war and the politics of ethics. In: Fagan, Madeleine; Glorieux, Ludovic; Hašimbegović, Indira; Suetsugu, Marie (eds.), Derrida: Negotiating the Legacy. Edinburgh: Edinburgh University Press, 97-111.

\section{К семиотике будущего: от предвидения к планированию}

Цель статьи - внести вклад в семиотические исследования будущего, объединяя различные подходы, касающиеся взаимоотношений человека с будущим. Следуя Николаю Бернштейну, статья рассматривает прогнозирование и предвидение как деятельность, основанную на моделировании (не)желаемого будущего. Такой подход к предвидению позволяет установить связи между психофизиологическими и семиотически опосредованными формами предвидения, с одной стороны, и между индивидуальной и коллективной формами предвидения, с другой. С учетом 
этих целей в статье предлагается сценарий семиотического подхода к будущему, основанный на принципах семиотических моделирующих систем, т.е. взгляд на будущее с точки зрения моделей будущего, а также семиотических ресурсов и процессов, участвующих в создании этих моделей. По мере того, как семиотические модели будущего становятся коллективными средствами познания и предвидения определенного будущего, можно говорить о коллективном предвидении, аналогичном понятию Юрия Лотмана о коллективной памяти. Таким образом, планирование, описанное Ричардом Грузином как ориентированная на будущее практика средств массовой информации, рассматривается как пример коллективного предвидения.

Кроме описания механизмов предвидения от индивидуальных до семиотически опосредованных коллективных форм, в статье также освещаются две фундаментальные теоретические проблемы: индивидуальное и коллективное вмешательство в формирование будущего и аффективное измерение предвидения.

\section{Tulevikusemiootika suunas: etteaimamisest ettevahendamiseni}

Artikliga püütakse anda panust semiootilistesse tuleviku-uuringutesse, joondades erinevaid lähenemisi, mis tegelevad suhetega, mis inimestel on tulevikuga. Täpsemalt keskendub artikkel etteaimamisele, mida vaadeldakse kui tegevust, mis tugineb Nikolai Bernsteini poolt välja pakutud soovitud/soovimatu tuleviku modelleerimisele. Mudelipõhine lähenemine etteaimamisele võimaldab luua seoseid ühelt poolt etteaimamise psühhofüsioloogiliste ja semiootiliselt vahendatud vormide vahel ning teisalt individuaalse ja kollektiivse etteaimamise vahel. Neid eesmärke silmas pidades visandatakse artiklis semiootiline lähenemine tulevikule, mis toetub semiootiliste modelleerivate süsteemide raamistusele, s.t vaatleb tulevikku, lähtudes selle mudelitest ning mudelite ehitamisesse kaasatud semiootilistest ressurssidest ja protsessidest. Et kultuuris ringlevatest semiootiliselt vahendatud tulevikumudelitest võivad saada kollektiivselt jagatavad vahendid mõnede tulevike tunnetamiseks ja etteaimamiseks, on analoogiliselt Juri Lotmani kultuurisemiootilise kollektiivse mälu mõistega võimalik rääkida kollektiivsest etteaimamisest. Ettevahendamist, tulevikule suunatud meediapraktikat, mille on visandanud Richard Grusin, vaadeldaksegi kollektiivse etteaimamise ühe näitena.

Artiklis uuritakse etteaimamismehhanisme individuaalsetest organismiga seotud vormidest kuni semiootiliselt vahendatud kollektiivsete vormideni ning lisaks tuuakse esiplaanile kaks fundamentaalset probleemi, mis läbivad selle lähenemise abil kokku toodud mitmesuguseid teoreetilisi perspektiive: individuaalne ja kollektiivne agentsus tuleviku loomisel ning etteaimamise afektiivne mõõde. 